\title{
STELLAR MOTIONS ALONG I = 60 - 240 AND I = 150 - 330 INHOMOGENEOUS FREQUENCY DISTRIBUTION OF SPECTRAL TYPES
}

\author{
S. Menge de FreitAS \\ Observatório do Valongo \\ Departamento de Astronomia - UFRJ
}

\begin{abstract}
Applications of the $\chi^{2}$ test to the frequency distribution of spectral types show a slight predominance of $A, F$ and $G$ stars running approximately along $I=60-240$; along the orthogonal direction, there seems to occur a preponderance of $\mathrm{K}$ and $\mathrm{M}$ stars.

Resumo - Aplicando-se o teste de Qui Quadrado às distribuiçð̋es de freqüências dos tipos espectrais, verifica-se uma certa predominancia de estrelas A, F e G movendo-se aproximadamente ao longo de $I=60 \cdot 240$; percorrendo a direçăo ortogonal a esta, parece ocorrer uma preponderância de estrelas $\mathrm{K} \in \mathrm{M}$.
\end{abstract}

\section{INTRODUCTION}

Usually studies on stellar kynematics seek to describe behaviours followed by groups (spectral types, luminosity classes, MK classifications) of stars, as well as to evaluate characteristic parameters of their motions. Therefore, the customary procedure is to take the stars themselves as starting-points. However, the present paper takes, not the stars, but the paths followed by them, as starting-points.

In our three previous papers on velocities of nearby stars (Freitas 1980, 1982, 1985) we have used components denoted by $\mathrm{L}$ (positive in the direction of Galactic Longitude $\mathrm{I}=60$ ) and $\mathrm{T}$ (positive in $\mathrm{I}=330$ ). In the first study, a sample of 726 stars, without sharp localization boundaries, was used. In the second and third papers, the sample was confined to a square centered in the Sun, with $36 \mathrm{pc}$ on each side; this reduced the sample to 631 stars. Distances to the galactic plane were not considered in the three papers. Referring again to ther first one, we have considered stars for wich $|\mathrm{T}|>3|\mathrm{~L}|,|\mathrm{T}|>$ $4|L|$ and $|T|>5|L|$, in order to see how perpendicular crossings of the longirude line $60-240$, in both senses, could affect dispersions in the $T$ component. The imposition of such conditions gave us subsamples with, respectively, 155, 111 and 93 stars.

In this study, we consider not only the three above conditions (confinement to the squares reducing subsamples to 137,101 and 83 stars respectively) but also stars for which $|\mathrm{L}|>3|\mathrm{~T}|,|\mathrm{L}|>4|\mathrm{~T}|$ and || $\mathrm{L} \mid>$ $5|\mathrm{~T}|$ (109, 79 and 59 stars). Factors 3, 4 and 5 imply in path deviations to the largest component no greater than $18.43,14.04$ and 11.31 , respectively (tables 1 through 6 only mention the first decimal).

Therefore, we consider two groups of paths, one approximately along longitude 150 or 330 , and the other approximately along 60 or 240 . Of course the paths here considered are not galactic orbits themselves, but only very tiny section of them.

\section{THE PROPOSED PROBLEM}

In papers I and II, the T components (approximately perpendicular to the direction 
of the local spiral arm) have shown and oddity in their behaviours, absolutely not shared by the $L$ components. This result suggests, at least, an inspection on stars running approximately along the directions which define $L$ and $T$.

Even though our stellar samples occupy a very small section of the Galaxy, we must recall that, as Woolley et al. (1969) observe, "these stars, although close to us at this moment, in many cases describe orbits in the Galaxy which take them to distances of one or more kiloparsecs from the Sun. Gliese's Catalogue is thus a sample of a much larger volume of the Galaxy than the space now occupied". We have then, in our vicinity, stars which are called "visitors" by Trumpler and Weaver (1953).

We shoud expect that such visitors must include a very large fraction of old stars. Their galactic orbits may have rosette shapes (Mihalas, 1968), and very hardly young stars could have suffered enough collisions as to deform in such way their original orbits. Therefore, we should expect to find a larger fraction of old stars running along our $T$ component than running along $\mathrm{L}$.

The sequence of spectral types from $A$ through $M$, even in Luminosity Class V (the vast majority in our samples), is a sequence of decreasing mass. Thus, it may be considered as a sequence of increasing longevity. Therefore, following this sequence, we increase the probability of finding old stars among the spectral types. Considering the indicators of old age and the data used in Table II of paper III, we see that, in a wider sample, the fraction of old stars grows from $\mathrm{G}$ to $\mathrm{M}$ spectral types.

We could expect, then, to find more $K$ and $M$ stars running along the $T$ component than along L. A simple counting in our samples show that, in fact, such predominance occurs.

On the other hand, from a sample of 137 stars wich run along the $T$ component itself, 150 or $330 \pm 18.4$, we have 116 stars of spectral types $G, K$ and $M$ with data for their orbital excentricities (Woolley et al., 1969) The averages for this parameter and respective standard deviations are

$2 \mathrm{G}$ stars: $\mathrm{e}=0.11 \mathrm{~s}=0.05$

$46 \mathrm{~K}$ stars $\mathrm{e}=0.11 \mathrm{~s}=0.07$
$=0.16 \mathrm{~s}=0.10$.

ges and dispersions suggest an

inc

thr

e number of old stars from $G$ ning along the above direction.

.ng the above items, a statistical

inve is seems to be justifiable, even for the si amples we have. Therefore, taking the paths 150 or 330 and 60 or 240 (whith the tolerance deviations already explanined) as starting-points, we try to verify if the spectral distribution of stars which run along these directions is homogeneous or not.

\section{THE METHOD}

We have usde the $\chi^{2}$ test in order to see whether the paths and spectral types are independent or not. Tables 1 to 6 refer to the cases for wich a $<0.100$ without applying Yates. Continuity Correction (YCC): for Tables 2 through 6 the significance level a obtained with the correction is also given (unchanged for Table 2).

In Table 1 we have one expected frequency smaller than 5; however, this Table has 10 cells, and one case of expected frequency with value between 2 and 5 , even among 5 cells, does not impair the reliability of the $\chi^{2}$ test (Choi, 1968, p. 109).

Different groupings of spectral types and one case of exclusion of $\mathrm{G}$ stars (to give a little more weight to extremes) are presented. for confirmation and comparison.

\section{CONCLUSIONS}

Among stars in the solar neighborhood which run approximately along $1=60-240$. there seems to occur a predominance of $A, F$ and $G$ spectral types, while the direction 150-330presentsa preponderance of $K$ and $M$ types. (This is to be considered only as an indicative result due to smallness of the samples here considered). Future work on larger samples may or not confirm this dichotomy.

Acknowledgements - We are deeply grateful to Maria Augusta Machado and J.A. Buarque for many suggestions. 
REFERENCES

Choi., S.C.: 1978, Introductory Applied Statistics in Science (Prentice Hall, Inc., Engle)

Freitas, S.M.: 1980, Astron. Astrophys. Suppl. Ser. 41,433

Freitas, S.M.: 1982, Astron. Astrophys. Suppl. Ser. 49,687

Freitas, S.M.: 1985, Astron. Astrophys. Suppl.

Ser. 60,63 .
Mihalas, P.: 1968, Galactic Astronomy (W.H. Freeman and Co., S.o Francisco and London).

Trumpler, R.J. and Weaver, H.F.: 1953 , Statistical Astronomy (University of California Press, Berkeley)

Woolley. R. et al.: 1969, Catalogue of Stars Within Twenty-Five Parsecs of the Sun (Royal Observatory Annals n.5)

CONTINGENCY TABLES

FOR DIRECTIONS AND SPECTRAL TYPES

Table 1

\begin{tabular}{|c|c|c|c|c|c|}
\hline DIR & $\begin{array}{c}60^{\circ} \\
\text { or } \\
24^{\circ}\end{array}$ & $\pm 18.4^{\circ}$ & $\begin{array}{c}150^{\circ} \\
\text { or } \\
330^{\circ}\end{array}$ & $\pm 18.4^{\circ}$ & TOTALS \\
\hline S.P & 8 & $(4.43)$ & 2 & $(2.57)$ & 10 \\
\hline f & 13 & $(11.96)$ & 14 & $(15.04)$ & 27 \\
\hline G & 27 & $(22.60)$ & 24 & $(28.40)$ & 51 \\
\hline K & 30 & $(43.56)$ & 48 & $(43.44)$ & 78 \\
\hline M & 31 & $(35.45)$ & 49 & $(44.55)$ & 80 \\
\hline Totals & 109 & \multicolumn{5}{|l}{$\alpha=0.100$} & 246 \\
\hline \multicolumn{7}{|l|}{} \\
\hline
\end{tabular}

Table 2

\begin{tabular}{|c|c|c|c|c|c|}
\hline DIR & $\begin{array}{c}60^{\circ} \\
\text { or } \\
240^{\circ}\end{array}$ & $\pm 18.4^{\circ}$ & $\begin{array}{c}150^{\circ} \\
\text { or } \\
330^{\circ}\end{array}$ & $\pm 18.4^{\circ}$ & TOTALS \\
\hline $\mathrm{A}+\mathrm{F}+\mathrm{G}$ & 48 & $(38.99)$ & 40 & $(49.01)$ & 88 \\
\hline $\mathrm{K}+\mathrm{M}$ & 61 & $(70.01)$ & 97 & $(87.99)$ & 158 \\
\hline Totals & 109 & 137 & 246 \\
\hline \multicolumn{5}{|c|}{$\begin{array}{l}\alpha=0.025 \\
\alpha=0.025 \text { with YCC }\end{array}$} \\
\hline
\end{tabular}

Table 3

\begin{tabular}{|c|c|c|c|c|c|}
\hline DIR & $\begin{array}{c}60^{\circ} \\
\text { or } \\
240^{\circ}\end{array}$ & $\pm 18.4^{\circ}$ & $\begin{array}{c}150^{\circ} \\
\text { or } \\
330^{\circ}\end{array}$ & $\pm 18.4^{\circ}$ & TOTALS \\
\hline $\mathrm{A}+\mathrm{F}$ & 21 & $(16.39)$ & 16 & $(20.61)$ & 37 \\
\hline $\mathrm{G}+\mathrm{K}+\mathrm{M}$ & 88 & $(92.61)$ & 121 & $(116.39)$ & 209 \\
\hline Totals & 109 & 137 & 246 \\
\hline \multicolumn{6}{|c|}{$\begin{array}{l}\alpha=0.100 \\
\alpha=0.100 \text { with YCC }\end{array}$} \\
\hline
\end{tabular}


Table 4

\begin{tabular}{|c|c|c|c|c|c|}
\hline $\begin{array}{l}\text { DIR } \\
\text { S.P }\end{array}$ & $\begin{array}{c}60^{\circ} \\
\text { or } \\
240^{\circ}\end{array}$ & $\pm 18.4^{\circ}$ & $\begin{array}{r}15 \\
0 \\
33\end{array}$ & $3.4^{\circ}$ & TOTALS \\
\hline$A+F$ & 21 & $(15.56)$ & 1 & 1.44) & 37 \\
\hline $\mathrm{K}+\mathrm{M}$ & 61 & $(66.44)$ & 9 & (91.56) & 158 \\
\hline \multirow[t]{2}{*}{ Totals } & 82 & & & 113 & 195 \\
\hline & & & $\begin{array}{l}=0 . \\
=0 .\end{array}$ & & \\
\hline
\end{tabular}

Table 5

\begin{tabular}{|c|c|c|c|c|c|}
\hline DIR & $\begin{array}{c}60^{\circ} \\
\text { or } \\
240^{\circ}\end{array}$ & $\pm 14^{\circ}$ & $\begin{array}{c}150^{\circ} \\
\text { or } \\
330^{\circ}\end{array}$ & $\pm 14^{\circ}$ & TOTALS \\
\hline $\mathrm{A}+\mathrm{F}+\mathrm{G}$ & 31 & $(24.58)$ & 25 & $(31.42)$ & 56 \\
\hline $\mathrm{K}+\mathrm{M}$ & 48 & $(54.42)$ & 76 & $(69.58)$ & 124 \\
\hline Totals & 79 & 101 & 180 \\
\hline \multicolumn{6}{|c|}{$\begin{array}{l}\alpha=0.50 \\
\alpha=0.100 \text { with YCC }\end{array}$} \\
\hline
\end{tabular}

Table 6

\begin{tabular}{|c|c|c|c|c|c|}
\hline DIR & $\begin{array}{c}60^{\circ} \\
\text { or } \\
240^{\circ}\end{array}$ & $\pm 11.3^{\circ}$ & $\begin{array}{c}150^{\circ} \\
\text { or } \\
330^{\circ}\end{array}$ & $\pm 11.3^{\circ}$ & TOTALS \\
\hline $\mathrm{A}+\mathrm{F}+\mathrm{G}$ & 24 & $(19.11)$ & 22 & $(26.89)$ & 46 \\
\hline $\mathrm{K}+\mathrm{M}$ & 35 & $(39.89)$ & 61 & $(56.11)$ & 96 \\
\hline Totals & 59 & 83 & 142 \\
\hline \multicolumn{5}{|c|}{$\begin{array}{l}\alpha=0.10 \\
\alpha=0.100 \text { with YCC }\end{array}$} \\
\hline
\end{tabular}

